\title{
Analisis Potensi Penyajian Prosedur Buku New Syllabus Mathematics Jilid II Dalam Meningkatkan Kemampuan Berpikir Kritis
}

\author{
Apriliana Tezha Eka Faradina ${ }^{1}$, Abdur Rahman As'ari ${ }^{1}$, Sukoriyanto ${ }^{1}$ \\ ${ }^{1}$ Pendidikan Matematika-Universitas Negeri Malang
}

\begin{tabular}{l}
\hline \hline INFO ARTIKEL \\
\hline Riwayat Artikel: \\
Diterima: 13-05-2019 \\
Disetujui: 16-11-2019 \\
\hline
\end{tabular}

\section{Kata kunci:}

potential analysis; critical thinking;

the new syllabus mathematics book;

analisis potensi;

berpikir kritis;

buku new syllabus mathematics

\author{
Alamat Korespondensi: \\ Apriliana Tezha Eka Faradina \\ Pendidikan Matematika \\ Universitas Negeri Malang \\ Jalan Semarang 5 Malang \\ E-mail: aprilianatezha@gmail.com
}

\begin{abstract}
ABSTRAK
Abstract: The main focus of this research is describing potential for presenting book procedures New Syllabus Mathematics volume II in graph of quadratic function in improving critical thinking skills. Critical thinking skills consists of interpretation, analysis, evaluation, and inference. This research used content analysis. The researcher have determined to analyze inverstigation and worked example. This research showed that the presentation of book procedures volume II have the potential to improve interpretation ability and analysis with $100 \%$.

Abstrak: Tujuan penelitian ini adalah mendeskripsikan potensi penyajian prosedur buku New Syllabus Mathematics jilid II materi grafik fungsi kuadrat dalam meningkatkan kemampuan berpikir kritis. Kemampuan berpikir kritis terdiri dari interpretasi, analisis, evaluasi, dan inferensi. Penelitian ini menggunakan pendekatan analisis isi. Peneliti memutuskan jenis penyajian prosedur yang dianalisis yaitu investigation dan worked example. Penelitian ini memberikan hasil bahwa penyajian prosedur buku NSM jilid II berpotensi dalam meningkatkan kemampuan interpretasi dan analisis dengan persentasi $100 \%$.
\end{abstract}

Pada abad ke-21, kemampuan-kemampuan yang wajib dimiliki oleh siswa untuk meningkatkan kualitas pendidikan yaitu creativity, critical thinking, communication and collaboration (4C). Kemampuan-kemampuan tersebut diperlukan siswa untuk memperoleh, mengelola dan memanfaatkan informasi untuk bertahan hidup pada keadaan yang selalu berubah dan kompetitif. Hal itu juga didukung oleh pendapat Carlgren (2013) menyatakan bahwa kemampuan berpikir kritis merupakan salah satu kemampuan sangat penting untuk berkembang sebagai warga negara di abad ke-21. Aizikovitsh-Udi \& Cheng (2015) menyatakan bahwa kemampuan berpikir kritis penting dan harus dimiliki oleh individu. Individu seringkali dihadapkan dengan pengambilan keputusan yang memerlukan penalaran, pemahaman, analisis dan evaluasi terhadap informasi yang diterima, sehingga dengan berpikir kritis memungkinkan seseorang untuk mengambil keputusan yang valid. Kemampuan mengkaji secara kritis, merupakan langkah awal yang harus dilakukan seseorang dalam menghadapi masalah, memperoleh informasi dari masalah, dan memanfaatkannya untuk menyelesaikannya (As'ari, 2016).

Berdasarkan hasil PISA dan TIMSS menunjukkan bahwa peringkat siswa Indonesia masih jauh tertinggal dari negara lain. Hasil survei dari PISA yang dikoordinasi oleh OECD pada tahun 2015 berada di peringkat ke-62 dari 70 negara partisipan dengan skor rata-rata 386. Hasil evaluasi dari TIMSS tidak jauh berbeda denga hasil PISA, di tahun 2015 menunjukkan bahwa pencapaian nilai domain kognitif matematika Indonesia berada pada peringkat ke 45 dari 50 negara partisipan. Berdasarkan pemaparan tersebut, memberikan gambaran bahwa kemampuan pemecahan masalah siswa Indonesia masih rendah sehingga berdampak pada kemampuan berpikir kritis. Hal itu berarti bahwa salah satu kemampuan yang wajib dimiliki oleh siswa yaitu berpikir kritis belum tercapai. Berdasarkan uraian tentang pentingnya berpikir kritis dan fakta di lapangan yang menunjukkan kemampuan berpikir kritis calon guru dan siswa masih rendah maka menjadi alasan utama perlunya meningkatkan kemampuan berpikir kritis.

Rendahnya kemampuan berpikir kritis siswa Indonesia menunjukkan bahwa berpikir kritis memang tidaklah mudah, tetapi kemampuan berpikir kritis dapat dipelajari dan dilatih. Kemampuan berpikir kritis harus dibelajarkan sejak dini karena mengingat pentingnya kemampuan berpikir kritis yang harus dimiliki oleh setiap individu. Hal yang dapat dilakukan untuk mendukungnya adalah memasukkan pembelajaran yang memuat kemampuan berpikir kritis dalam kurikulum pendidikan. Pembelajaran menekankan kemampuan berpikir kritis siswa sehingga menghasilkan pengalaman pembelajaran yang bermakna dan berharga bagi siswa dan guru (Duron, dkk, 2006). Pembelajaran matematika merupakan salah satu pembelajaran yang dapat 
melatih kemampuan berpikir kritis siswa. Oleh karena itu, dalam pembelajaran matematika sudah seharusnya siswa dibekali kemampuan berpikir kritis dengan aktivitas melatih, mengajak, dan memberi contoh tentang berpikir kritis.

Kegiatan pembelajaran tidak pernah terlepas dari sumber belajar. Salah satu sumber belajar yang digunakan dalam proses pembelajaran yaitu buku teks. Buku teks merupakan salah satu penunjang kegiatan pembelajaran. Dalam pembelajaran, buku teks digunakan untuk mewakili interaksi antara siswa dengan guru, siswa dengan pengetahuan serta guru dengan pengetahuan. Penggunaan buku teks berperan penting dalam kegiatan pembelajaran. Menurut Seguin (1989) buku teks memiliki tiga peran utama yaitu penyediaan informasi dan pengetahuan, penataan dan pengorganisasian pembelajaran serta panduaan pembelajaran. Buku teks mampu meningkatkan kemampuan berpikir kritis siswa apabila buku teks tersebut sudah memenuhi tiga kriteria yaitu multiple perspective, plentiful evidence of critique throughtout the text dan contextualized content (Errington \& Bubna-Litic, 2015). Dalam buku teks terdapat komponen-komponen salah satunya teks (Gardiner, 2014) (Weinberg \& Wiesner, 2012). Pada bagian teks terdapat materi yang akan dipelajari, misalnya definisi, teorema ataupun prosedur. Prosedur disajikan pada fitur contoh soal (examples) yang terdapat teknik atau langkah-langkah dalam memperoleh suatu penyelesaian tertentu. Penguasaan prosedur diperlukan untuk menyelesaikan suatu permasalahan dengan langkah-langkah atau teknik yang dimiliki. Hal tersebut selaras dengan pendapat Gardiner (2014) yang menyatakan bahwa kefasihan dalam prosedur matematika penting diakui sebagai tujuan dalam pembelajaran matematika sekolah.

Berdasarkan hasil PISA dan TIMSS di Indonesia tentang kemampuan berpikir kritis, tampak sangatlah berbeda dengan negara Singapura. Kemampuan berpikir kritis siswa Singapura berada pada kategori tinggi. Hal ini ditunjukkan dengan hasil survei dari PISA, bahwa Singapura menempati peringkat 1 dari 70 negara partisipan pada tahun 2015. Sejalan dengan hasil PISA, TIMSS menunjukkan bahwa Singapura juga menempati peringkat 1 dari 49 negara partisipan. Soal-soal yang digunakan pada PISA dan TIMSS merupakan soal yang berkategori soal tipe High Order Thinking Skills (HOTS) (Wu, 2009). Soal HOTS memuat kemampuan berpikir kritis dan berpikir kreatif (Heong dkk., 2011).

Keberhasilan negara Singapura pada PISA dan TIMSS tidak terlepas dari kurikulum pembelajaran yang dirancang. Hal itu selaras dengan pendapat Kaur (2014) menyatakan bahwa kurikulum, guru, siswa, dan lingkungan belajar dapat dikatakan memberikan kontribusi terhadap kinerja Singapura dalam studi yang berstandar internasional, seperti TIMSS dan PISA. Hanya kurikulum yang dirancang secara ketat dapat mendorong kompetensi berpikir kritis siswa Singapura (Tan, dkk., 2017). Berdasarkan penjelasan tersebut tidak ada penelitian tentang potensi buku teks matematika Singapura dalam meningkatkan kemampuan berpikir kritis. Untuk itu, buku teks matematika Singapura dipilih pada penelitian ini berdasarkan kenyamanan peneliti tentang bahasa. New Syllabus Mathematics (NSM) dipilih sebagai buku teks perwakilan dari Singapura karena hanya buku teks NSM yang disetujui oleh Departemen Pendidikan (MoE) untuk digunakan di sekolah. Selain itu, berdasarkan penelitian Yang (2017), NSM memiliki nilai tertinggi saham (80\%) di Singapura.

Peneliti memilih materi fungsi untuk dianalisis karena materi fungsi merupakan salah satu materi penting dalam kurikulum matematika sekolah. Fungsi digunakan dalam setiap cabang matematika sebagai operasi aljabar pada bilangan, transformasi pada titik-titik di bidang atau di ruang, irisan dan gabungan pada himpunan, dan sebagainya (Denbel, 2015). Fungsi adalah konsep pemersatu dalam semua matematika. Pada penelitian ini fokus pada materi grafik fungsi kuadrat.

\section{METODE}

Penelitian ini menggunakan pendekatan analisis isi (content analysis). Data yang menjadi bahan kajian dalam penelitian ini adalah buku NSM (New Syllabus Mathematics $7^{\text {th }}$ Edition) jilid II materi grafik fungsi kuadrat. Komponen data penelitian berupa potensi penyajian prosedur dalam meningkatkan kemampuan berpikir kritis. Kemampuan berpikir kritis terdiri dari interpretasi, analisis, evaluasi, dan inferensi. Peneliti memutuskan jenis penyajian prosedur yang dianalisis yaitu investigation dan worked example. Setelah membaca dengan cermat NSM jilid II, peneliti kemudian memutuskan untuk menganalisis potensi penyajian prosedur yang terkandung dalam buku teks yang terkait judul investigation dan worked example. Instrumen yang digunakan berupa pedoman analisis. Pedoman analisis digunakan untuk mengungkap potensi penyajian prosedur pada NSM jilid II dalam meningkatkan kemampuan berpikir kritis.

\section{HASIL}

Deskripsi hasil penelitian ini fokus pada potensi penyajian prosedur materi grafik fungsi kuadrat NSM jilid II dalam meningkatkan kemampuan berpikir kritis. Terdapat total tujuh judul yang merupakan penyajian prosedur. Berdasarkan tabel dapat disimpulkan bahwa potensi kemampuan berpikir kritis pada penyajian prosedur buku matematika Singapura jilid II, kemampuan interpretasi dan analisis terdapat pada seluruh penyajian prosedur dengan persentase $100 \%$, kemampuan evaluasi dengan persentase $80,9 \%$ serta kemampuan inferensi dengan persentase 95,2\%. Berdasarkan tabel, bentuk penyajian prosedur yang berpotensi meningkatkan kemampuan berpikir kritis yaitu investigation pada halaman 129, 130, dan 131 serta worked example 10 pada halaman 137. Berdasarkan penilaian tersebut, yang dibahas pada artukel ini fokus pada yaitu investigation (hal. 131). Hasil penilaian kemampuan berpikir kritis pada NSM jilid II disajikan pada tabel 1. 
Tabel 1. Penilaian Kemampuan Berpikir Kritis

\begin{tabular}{lccccc}
\hline \multirow{2}{*}{ Judul } & Hal & \multicolumn{5}{c}{ Kemampuan Berpikir Kritis } \\
\cline { 3 - 6 } & & Interpretasi & Analisis & Evaluasi & Inferensi \\
\hline Investigation & 129 & 3 & 3 & 3 & 3 \\
Investigation & 130 & 3 & 3 & 3 & 3 \\
Investigation & 131 & 3 & 3 & 3 & 3 \\
Worked Example 7 & 133 & 3 & 3 & 1 & 2 \\
Worked Example 8 & 134 & 3 & 3 & 2 & 3 \\
Worked Example 9 & 135 & 3 & 3 & 2 & 3 \\
Worked Example 10 & 137 & 3 & 3 & 3 & 3 \\
& & & & & 20 \\
\hline Total & & 21 & 21 & 17 & $95,2 \%$ \\
\hline Persentase & & $100 \%$ & $100 \%$ & $80,9 \%$ & \\
\hline
\end{tabular}

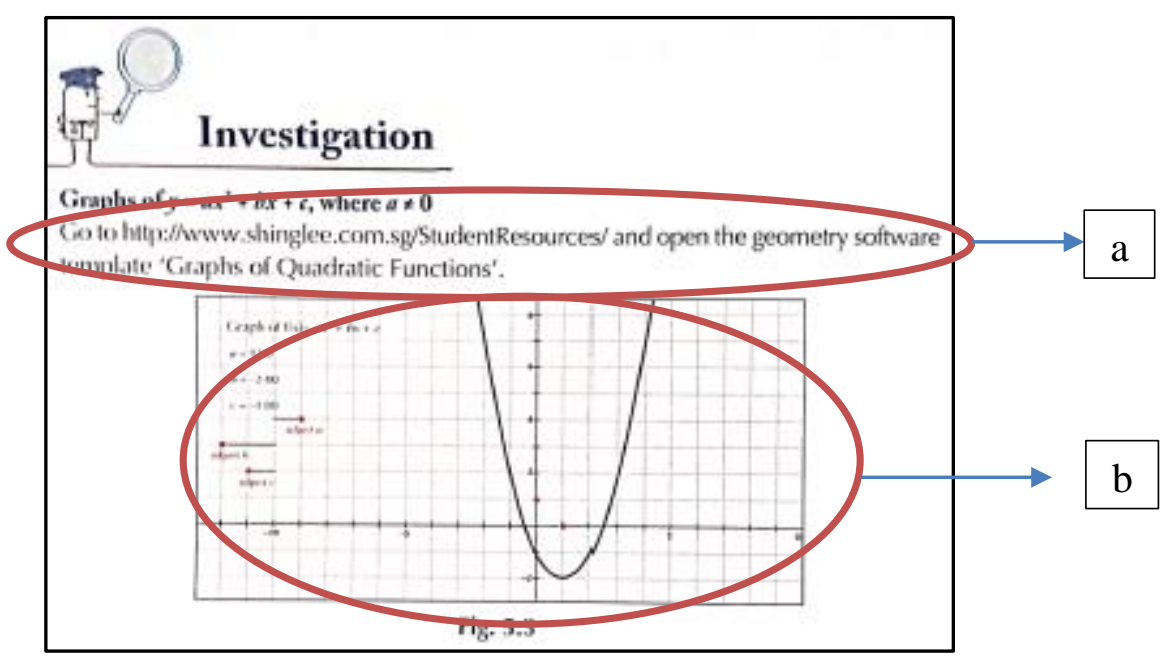

Gambar 1. Investigation pada Grafik $y=a x^{2}+b x+c, a \neq 0$

Part I: Efifect of Value of $a$

For this mart of the investigati adjust the value of $b$ and of $c$ to 0

1 Increase the value of $a$. Yhat do you notice about the shape of the graph?

2. Decreme the rutve of $a$ but ensure that it is positive- What do you notice

aloout the shape of the graph?

3. Decrease the value of $a$ until it becomes negative. What do you notice about

the shape of the graph?

4. How does the value of $a$ affect the shape of the graph? What happens when $a$ is prositive and when a is negative?

Gambar 2. Investigation Pengaruh Nilai $a$ pada Grafik $y=a x^{2}+b x+c, a \neq 0$

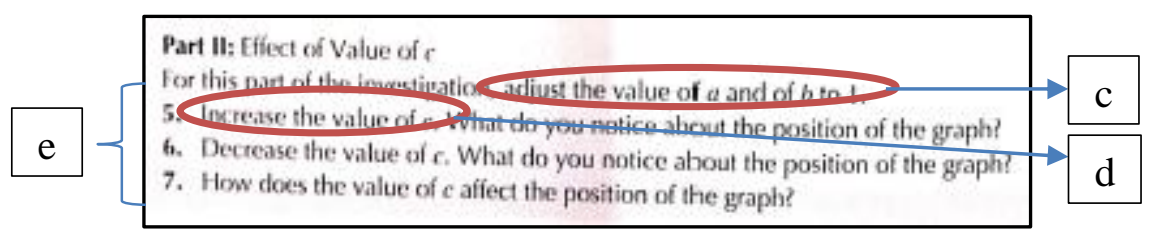

Gambar 3. Investigation Pengaruh Nilai $c$ pada Grafik $y=a x^{2}+b x+c, a \neq 0$ 


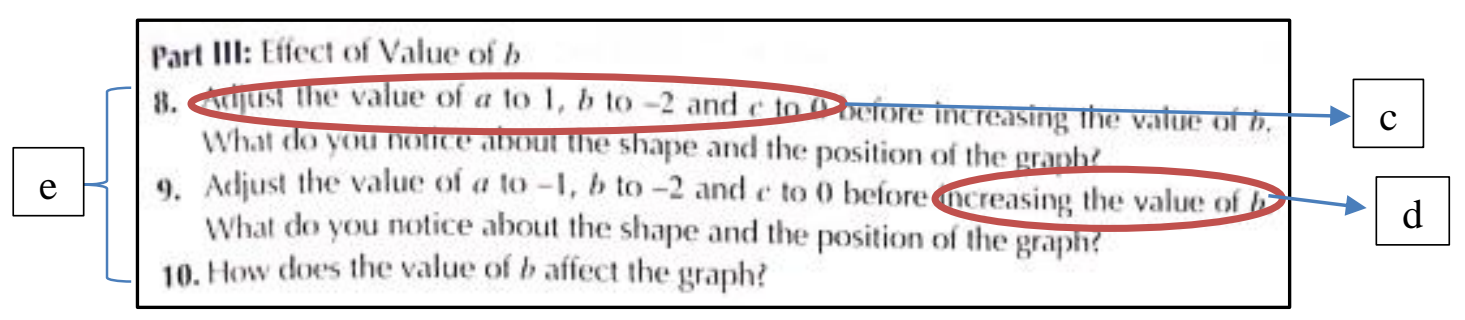

Gambar 4. Investigation Pengaruh Nilai $b$ pada Grafik $y=a x^{2}+b x+c, a \neq 0$

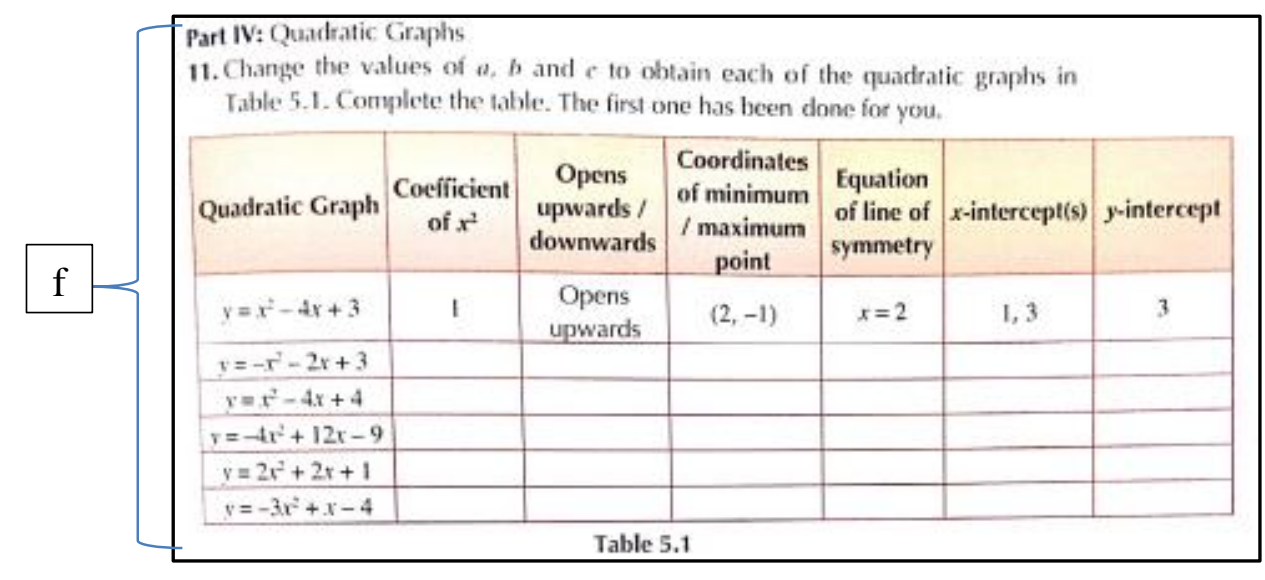

Gambar 5. Tabel Investigation pada Grafik $y=a x^{2}+b x+c, a \neq 0$

Berdasarkan tabel 1, investigation menunjukkan bahwa pada kemampuan interpretasi memperoleh skor 3 . Skor 3 berarti bahwa investigation memenuhi dua indikator yaitu mampu mendorong siswa menggolongkan informasi penting dan menentukan makna dari informasi yang tersedia. Berdasarkan gambar 1, 2, 3, dan 4 terdapat poin a, b, dan d yang berpotensi meningkatkan kemampuan interpretasi. Pada poin a merupakan bagian awal kegiatan investigasi yang mampu mendorong siswa untuk menggolongkan informasi pada pernyataan tersebut penting atau tidak. Penggunaan software merupakan salah satu alternatif cara untuk mempermudah menggambar grafik fungsi. Poin a juga merupakan instruksi awal yang mampu mendorong siswa untuk menentukan makna dari pernyataan tersebut. Poin b merupakan bagian dari tampilan software apabila sudah digunakan, bagian tersebut mampu mendorong siswa untuk memahami dan menentukan makna pada setiap komponennya. Poin c pada gambar 2 terdapat kalimat bahwa untuk nilai $b$ dan $c$ harus 0 . Kalimat tersebut mendorong siswa untuk menggolongkan informasi pada kalimat itu penting atau tidak. Alasan nilai $b$ dan $c$ ditentukan harus 0 karena pada kegiatan tersebut ingin mengetahui pengaruh koefisien $a$ terhadap bentuk grafik. Begitu juga dengan poin c pada gambar 3 dan 4 . Poin d pada gambar 2 terdapat kalimat atau instruksi yaitu "tingkatkan nilai atau koefisien $a$ ", kalimat tersebut mendorong siswa untuk menentukan makna pada kata "tingkatkan". Pada kalimat tersebut koefisien atau nilai a yang harus ditingkatkan tidak terdapat ketentuan, sehingga siswa diminta untuk menentukan interval koefisien atau nilai a sesuai keinginan sendiri. Begitu juga dengan poin d pada gambar 3 dan 4 .

Berdasarkan tabel 1, investigation pada kemampuan analisis memperoleh skor 3. Skor 3 berarti bahwa investigation memenuhi dua indikator, yaitu mampu mendorong siswa mengidentifikasi hubungan antara pernyataan/kalimat sebagai informasi penting dengan penyajian tabel/grafik serta terdapat kegiatan menganalisis informasi yang tersedia. Berdasarkan gambar 2, 3, dan 4 terdapat poin e yang merupakan bagian penyajian prosedur dan berpotensi meningkatkan kemampuan analisis. Pada gambar 2, poin e terdapat empat instruksi yang merupakan bagian dari penyajian prosedur dalam menentukan pengaruh nilai $a$. Keempat instruksi di atas sebagai informasi penting untuk mendorong siswa mengidentifikasi dan menganalisis hasil grafik yang diperoleh pada software. Perbedaan perlakuan setiap instruksi pada koefisien atau nilai $a$ mendorong siswa untuk menganalisis setiap perbedaan grafik yang dihasilkan. Sama halnya dengan gambar 3 dan 4 juga terdapat tiga instruksi yang merupakan informasi penting sehingga mendorong siswa untuk berpikir analisis.

Berdasarkan tabel 1, investigation pada kemampuan evaluasi memperoleh skor 3. Skor 3 berarti investigation memenuhi dua indikator kemampuan evaluasi yaitu terdapat kegiatan penilaian kualitas analisis dan mampu mendorong siswa memberikan alasan logis. Pada investigation gambar 2, 3, dan 4 terdapat pernyataan atau instruksi yang berpotensi untuk meningkatkan kemampuan evaluasi. Pada setiap instruksi memberikan perlakuan yang berbeda nilai $a$ sehingga mendorong siswa untuk melakukan penilaian terhadap kualitas yang dianalisis. Pada setiap instruksi juga terdapat pertanyaan yang mendorong siswa untuk memberikan alasan terhadap hasil yang diperoleh pada software. 
Berdasarkan tabel 1, investigation pada kemampuan inferensi memperoleh skor 3. Skor 3 berarti investigation (hal. 131) memenuhi dua indikator, yaitu mampu mendorong siswa menunjukkan bukti dan mampu mendorong siswa membuat atau membangun prosedurnya sendiri. Keseluruhan kegiatan pada investigation mampu mendorong siswa menunjukkan bukti terhadap hasil yang diperoleh. Bukti diperoleh dari hasil penyelidikan grafik pada software. Poin $\mathrm{f}$ pada gambar 5 terdapat tabel yang merupakan kesimpulan dari tiga kegiatan sebelumnya. Pada tabel tersebut terdapat beberapa kolom yang harus dilengkapi. Pada kegiatan tersebut mendorong siswa untuk membuat prosedurnya sendiri sehingga mampu untuk melengkapi tabel. Apabila siswa mampu berpikir interpretasi, analisis dan evaluasi dalam menyelesaikan kegiatan satu sampai tiga maka siswa tersebut juga mampu berpikir inferensi pada kegiatan empat.

\section{PEMBAHASAN}

Penyajian prosedur pada buku New Syllabus Mathematics jilid II pada keseluruhan judul berpotensi meningkatkan kemampuan interpretasi. Pada keseluruhan judul tersebut mampu mendorong siswa menggolongkan informasi penting dan menentukan makna dari informasi yang tersedia. Informasi yang tersedia pada investigation dan worked example merupakan langkah utama untuk memahami maksud dari penyajian prosedur yang ada. Hal tersebut selaras dengan temuan Ponte (2007) dan (Atkinson, dkk., 2015). Ponte mengemukakan bahwa investigation dimulai dengan sekumpulan informasi yang terstruktur. Atkinson, dkk mengemukakan bahwa worked example harus dibangun secara maksimal dari informasi yang tersedia, misalnya diagram dan teks. Hal tersebut juga selaras dengan temuan Gracin (2018). Gracin menyatakan bahwa interpretasi mencakup kegiatan memberikan makna yang tepat dari representasi informasi yang tersedia, misalnya grafik. Kegiatan interpretasi terdiri dari membaca data dari gambar yang diberikan misalnya membaca nilai-nilai grafik yang diberikan.

Penyajian prosedur buku NSM jilid II pada keseluruhan judul berpotensi meningkatkan kemampuan analisis. Pada keseluruhan judul tersebut mampu mendorong siswa mengidentifikasi hubungan antara pernyataan atau kalimat sebagai informasi penting dengan penyajian tabel atau grafik serta menganalisis informasi yang tersedia. Hal tersebut selaras dengan pendapat Atkinson, dkk (2000). Atkinson menyatakan bahwa worked example mengharuskan siswa untuk mengidentifikasi informasi dari masalah dengan penjelasan secara tekstual.

Penyajian prosedur buku New Syllabus Mathematics jilid II terdapat empat judul yang berpotensi meningkatkan kemampuan evaluasi. Empat judul tersebut memuat kegiatan penilaian kualitas analisis dan mampu mendorong siswa untuk memberikan alasan logis. Berdasarkan hasil analisis, pada investigation dan worked example terdapat pertanyaan-pertanyaan ataupun pernyataan tersirat yang mendorong siswa untuk memberikan alasan logis. Hal tersebut selaras dengan temuan Aslan \& Polat (2008). Jacobs dan Aslan menyatakan bahwa pertanyaan-pertanyaan pada buku teks dapat memberikan peluang untuk menggunakan perspektif yang berbeda antara siswa satu dengan lainnya. Selain itu, dengan pertanyaan-pertanyaan mendorong siswa untuk memberikan pendapat atau alasan.

Penyajian prosedur buku New Syllabus Mathematics jilid II terdapat enam judul yang berpotensi meningkatkan kemampuan inferensi. Enam judul tersebut mampu mendorong siswa menunjukkan bukti dan membangun atau membuat prosedur menggunakan bahasa sendiri. Berdasarkan hasil analisis, kegiatan menunjukkan bukti terdapat pada bagian penyajian prosedur yang memungkinkan siswa untuk menggunakan cara lain dalam menyelesaikan masalah. Ponte (2007) karakteristik dari proses penyelidikan salah satunya yaitu proses membuktikan.

\section{SIMPULAN}

Penyajian prosedur (investigation dan worked example) materi grafik fungsi kuadrat pada buku New Syllabus Mathematics jilid II berpotensi meningkatkan kemampuan interpretasi dan analisis. Keseluruhan penyajian prosedur mampu mendorong siswa menggolongkan informasi penting dan menentukan makna dari informasi yang tersedia. Keseluruhan judul juga mampu mendorong siswa mengidentifikasi hubungan antara pernyataan atau kalimat sebagai informasi penting dengan penyajian tabel atau grafik serta menganalisis informasi yang tersedia.

Dari penelitian ini, ada beberapa saran yang diberikan kepada penulis buku NSM dan peneliti selanjutnya. Saran yang dapat diberikan untuk penulis buku New Syllabus Mathematics yaitu lebih menambahkan aspek evaluasi dan inferensi pada penyajian prosedur. Saran yang dapat diberikan untuk peneliti selanjutnya yaitu bisa menggunakan materi selain fungsi dan komponen-kompenan lain dari buku teks tersebut.

\section{DAFTAR RUJUKAN}

Aizikovitsh-Udi, E., \& Cheng, D. (2015). Developing Critical Thinking Skills from Dispositions to Abilities: Mathematics Education from Early Childhood to High School. Creative Education, 06(04), 455-462. https://doi.org/10.4236/ce.2015.64045

As'ari, A. R. (2016). Pengembangan 4C's dalam Pembelajaran Matematika: Sebuah Tantangan Pengembangan Kurikulum matematika [Seminar Nasional Pendidikan Matematika Pascasarjana]. Universitas Negeri Malang.

Aslan, C., \& Polat, D. (2008). Content Analysis on Primary Education Turkish Course Books from the Point of Acquiring Critical Thinking Skills. Issues on Education and Research, 1, 147-160. The Athens Institute for Education and Research. 
Atkinson, R. K., Derry, S. J., Renkl, A., \& Wortham, D. (2015). Learning from Examples: Instructional Principles from the Worked Examples Research. Review of Education Research, 70(2), 181-214.

Carlgren, T. (2013). Communication, Critical Thinking, Problem Solving: A Suggested Course for All High School Students in the 21st Century. Interchange, 44(1-2), 63-81. https://doi.org/10.1007/s10780-013-9197-8

Denbel, D. G. (2015). Functions in the Secondary School Mathematics Curriculum. Journal of Educational and Practice, 6(1), 77-81.

Duron, R., Limbach, B., \& Waugh, W. (2006). Critical Thinking Framework for any Discipline. International Journal of Teaching and Learning in Higher Education, 17(2), 160-166.

Errington, A., \& Bubna-Litic, D. (2015). Management by Textbook: The Role of Textbooks in Developing Critical Thinking. Journal of Management Education, 39(6), 774-800. https://doi.org/10.1177/1052562915594839

Gardiner, A. D. (2014). Teaching Mathematics at Secondary Level. The De Morgan Gazette, 6(1), 1-215.

Glasnovic Gracin, D. (2018). Requirements in Mathematics Textbooks: A Five-Dimensional Analysis of Textbook Exercises and Examples. International Journal of Mathematical Education in Science and Technology, 49(7), $1003-1024$. https://doi.org/10.1080/0020739X.2018.1431849

Heong, Y. M., Othman, W. B., Yunos, J. B. M., Kiong, T. T., Hassan, R. B., \& Mohamad, M. M. B. (2011). The Level of Marzano Higher Order Thinking Skills among Technical Education Students. International Journal of Social Science and Humanity, 1(2), 121-125.

Kaur, B. (2014). Mathematics Education In Singapore-An Insider's Perspective. IndoMS-JME, 5(1), 1-16.

Ponte, J. (2007). Investigations and Explorations In The Mathematics Classroom. ZDM Mathematics Education, 39(5-6), 419430.

Seguin, R. (1989). The Elaboration of School Textbooks. UNESCO: Division of Educational Sciences, Contents and Methods of Education.

Tan, L. S., Koh, E., Lee, S. S., Ponnusamy, L. D., \& Tan, K. C. K. (2017). The Complexities in Fostering Critical Thinking Through School-Based Curriculum Innovation: Research Evidence from Singapore. Asia Pacific Journal of Education, 37(4), 517-534. https://doi.org/10.1080/02188791.2017.1389694

Wu, M. (2009). A Critical Comparison of the Contents of PISA and TIMSS Mathematics Assessments. University of Melbourne, Australia.

Yang, D. C. (2017). A Comparison of Geometry Problems in Middle-Grade Mathematics Textbooks from Taiwan, Singapore, Finland, and the United States. EURASIA Journal of Mathematics, Science and Technology Education, 13. https://doi.org/10.12973/eurasia.2017.00721a 